\title{
Association of nuclear and mitochondrial genes with audiological examinations in Iranian patients with nonaminoglycoside antibiotics-induced hearing loss
}

\author{
This article was published in the following Dove Press journal: \\ Therapeutics and Clinical Risk Management \\ 28 January 2016 \\ Number of times this article has been viewed
}

\section{Maryam Balali, ${ }^{1,2}$ \\ Behnam Kamalidehghan ${ }^{3}$ \\ Mohammad Farhadi ${ }^{2}$ \\ Fatemeh Ahmadipour ${ }^{4}$ \\ Mahmoud Dehghani \\ Ashkezari' \\ Mohsen Rezaei Hemami ${ }^{2}$ \\ Hossein Arabzadeh ${ }^{2}$ \\ Masoumeh Falah ${ }^{2}$ \\ Goh Yong Meng ${ }^{5}$ \\ Massoud Houshmand ${ }^{3}$}

'Department of Biology, Islamic Azad University, Ashkezar Branch, Ashkezar, ${ }^{2}$ Department and Research Centre of ENT and Head \& Neck Surgery, Iran University of Medical Sciences, Tehran, Iran; ${ }^{3}$ Medical Genetics Department, National Institute of Genetic Engineering and Biotechnology, Tehran, Iran; ${ }^{4}$ Department of Pharmacy, Faculty of Medicine, University of Malaya, Kuala Lumpur, ${ }^{5}$ Department of Veterinary Preclinical Sciences, Faculty of Veterinary Medicine, Universiti Putra Malaysia, Serdang, Malaysia
Correspondence: Massoud Houshmand Medical Genetics Department, National Institute of Genetic Engineering and Biotechnology, Tehran, Iran Tel +98 2l 44580390 Fax +98 2I 44580399

Email massoudh@nigeb.ac.ir

\begin{abstract}
Mitochondrial DNA mutations play an important role in causing sensorineural hearing loss. The purpose of this study was to determine the association of the mitochondrial genes RNR1, MT-TL1, and ND1 as well as the nuclear genes GJB2 and GJB6 with audiological examinations in nonfamilial Iranians with cochlear implants, using polymerase chain reaction, DNA sequencing, and RNA secondary structure analysis. We found that there were no novel mutations in the mitochondrial gene $12 S$ rRNA ( $M T-R N R 1$ ) in patients with and without GJB2 mutation (GJB2+ and GJB2-, respectively), but a total of six polymorphisms were found. No mutations were observed in $t R N A^{\operatorname{Leu}(U U R)}$ (MT-TL1). Furthermore, eight polymorphisms were found in the mitochondrial ND1 gene. Additionally, no mutations were observed in the nuclear GJB6 gene in patients in the GJB2- and GJB2 ${ }^{+}$groups. The speech intelligibility rating and category of auditory perception tests were statistically assessed in patients in the GJB2 ${ }^{-}$and $\mathrm{GJB}^{+}$groups. The results indicated that there was a significant difference $(P<0.05)$ between the categories of auditory perception score in the GJB2 ${ }^{-}$group compared to that in the GJB2 ${ }^{+}$ group. Successful cochlear implantation was observed among individuals with GJB2 mutations $\left(\mathrm{GJB}^{+}\right)$and mitochondrial polymorphisms compared to those without GJB2 mutations (GJB2-). In conclusion, the outcome of this study suggests that variation in the mitochondrial and nuclear genes may influence the penetrance of deafness. Therefore, further genetic and functional studies are required to help patients in making the best choice for cochlear implants.
\end{abstract}

Keywords: mitochondrial $12 S$ rRNA (MT-RNR1) gene, mitochondrial $t R N A^{\operatorname{Leu}(U U R)}$ (MT-TL1) gene, MT-ND1, nuclear GJB2 and GJB6 genes, cochlear implant, sensorineural hearing loss

\section{Introduction}

Hearing loss (HL) is one of the most common sensory disorders in humans affecting one to three of every 1,000 newborns. ${ }^{1}$ The onset of HL usually occurs in childhood, is predominantly postlingual, and may be accompanied by vertigo ${ }^{2}$ and tinnitus. ${ }^{3,4}$ There is a high variability in severity, ranging from normal hearing to profound deafness. ${ }^{5,6}$ This may be due to the fact that the phenotypic effects are a result of several factors and can develop gradually. ${ }^{7}$ HL occurs in both syndromic and nonsyndromic deafness caused by mitochondrial DNA (mtDNA) mutations, ${ }^{8}$ where both environmental and genetic factors are also involved, such as noise pollution, use of aminoglycoside drugs, and genomic diversity. ${ }^{9}$ mtDNA mutations are responsible for both maternally inherited syndromic and nonsyndromic HL and play a role in predisposition to aminoglycoside-induced ototoxicity. ${ }^{10}$ In Italy, at least $5 \%$ of cases of postlingual, nonsyndromic hearing impairment may be attributed to mtDNA mutations. ${ }^{1}$ Furthermore, 
it has been estimated that in up to $67 \%$ of patients with and without GJB2 mutations (GJB2+ and GJB2- ${ }^{-}$, respectively), mtDNA disorders also manifest as sensorineural hearing loss (SNHL). ${ }^{11}$ SNHL associated with mtDNA mutations is generally progressive with high frequency. ${ }^{12-15}$ This may be explained by the high oxidative phosphorylation demands in cochlear cells, as conveyed by mtDNA mutations. ${ }^{1}$

Human mtDNA is a 16,569-bp, circular, double-stranded molecule that encodes 37 genes, including 13 subunits of the respiratory chain complexes, two ribosomal RNAs, and 22 transfer RNAs. Each nucleated human cell contains a few thousand copies of mtDNA. The somatic mutation rate of mtDNA is presumed to be 10-20 times higher than that of nuclear DNA (nDNA). ${ }^{16}$ Mitochondria are essentially doublemembraned subcellular organelles present in all nucleated mammalian cells. Their primary function is to support aerobic respiration, that is, the production of adenosine triphosphate through oxidative phosphorylation. ${ }^{17}$ In addition, mutations and/or polymorphism variance in mitochondrial genes play important roles and are related to many diseases, such as Leber's hereditary optic neuropathy, ${ }^{18}$ Friedreich's ataxia, ${ }^{19}$ autism, ${ }^{20}$ Alzheimer's disease, ${ }^{21}$ oculocutaneous albinism type 1,22 recurrent pregnancy loss, ${ }^{23}$ and different cancers, such as gastric, ${ }^{24,25}$ bladder, ${ }^{26}$ colorectal, ${ }^{27}$ and breast. ${ }^{24}$

HL is caused by genetic or nongenetic factors. The nongenetic risk factors for HL during the neonatal period include treatment in a neonatal intensive care unit, craniofacial anomalies, meningitis, ${ }^{28,29}$ and cytomegalovirus infections. ${ }^{30} \mathrm{mtDNA}$ variants, including mutations, deletions, and insertions, particularly in the MT-RNR1 gene, have been identified to play an important role in patients with SNHL associated with or without a history of aminoglycoside therapy, suggesting that this locus in particular is a hotspot for deafness-associated mutations. ${ }^{31,32}$ The MT-TL1 gene encoding mitochondrial $t R N A^{\operatorname{Leu}(U U R)}$ is a hotspot for pathogenic mtDNA mutations, ${ }^{33}$ and a previous study reported the possible role of $M T$-TL1 in nonsyndromic disease. ${ }^{9}$ Mutations in this region cause severe myopathy with respiratory insufficiency, ${ }^{33,34}$ as this region is highly conserved among mammals. ${ }^{35}$ mtDNA mutations, in particular T3308C, have been identified to induce a significant decrease in the levels of the $M T-N D 1$ gene, suggesting that mutations in this region can increase the penetrance of deafness in patients with HL. ${ }^{1,36}$ Mutations in the nuclear GJB2 and GJB6 genes on the DFNB1 locus at chromosome 13q11-q12 are responsible for up to $50 \%$ of the most common causes of prelingual onset, recessively inherited nonsyndromic SNHL in humans, encoding the gap junction proteins connexin 26 (Cx26) and connexin 30 , respectively, ${ }^{37,38}$ and play a role in cochlear homeostasis. ${ }^{39}$ Recessive mutations in the GJB2 gene are the most common cause of hearing impairment ${ }^{40}$ affecting both paternal and maternal alleles. ${ }^{40,41}$ Thus, in order to estimate the incidence ratio of mutation in the next generation, the frequency of the mutation is to be ascertained. ${ }^{41,42}$ The GJB2 gene is the most common cause of the congenital HL, ${ }^{43}$ and the mutation spectra are different among different ethnic groups. ${ }^{42}$ It is essential to investigate the carrier frequency and mutation spectrum of each genetic background in order to provide more precise genetic counseling. The GJB2 gene encodes Cx26, a member of the connexin family of proteins that are constituents of the intercellular gap junction. ${ }^{44}$ The first GJB2 mutation was reported by Kelsell et al, ${ }^{45}$ in which c.35delG is the most common mutation in the Caucasian population while c. $235 \mathrm{delC}$ and p.Val37Ile are the most common mutations in the Asian population. ${ }^{42,46}$ In this study, we aimed to compare the impact of mutations in the mitochondrial $12 S \operatorname{rRNA}$ (MT-RNR1), tRNA $A^{\operatorname{Leu}(U U R)}$ (MT-TL1), and ND1 on Iranian patients with nuclear GJB2 mutation $\left(\mathrm{GJB}^{+}\right)$and without GJB2 mutation (GJB2-) undergoing cochlear implants.

\section{Materials and methods \\ Specimen collection and ethical statement}

In this study, blood samples from 84 patients who had prelingual deafness with normal cochlear structures were obtained from the Rasoul Akram Hospital, Tehran, Iran. The patients did not show any syndromic symptoms or other clinical abnormalities, including muscular diseases, diabetes, visual dysfunction, or neurological disorders. Eighty-four patients with cochlear implant were categorized into two groups including 24 patients without GJB2 (GJB2-) mutations and 60 patients with $G J B 2\left(\mathrm{GJB}^{+}\right)$mutations. Written informed consent, including consent to participate in this study and consent to submission and publish, was obtained from the parents on behalf of their children in accordance with the Medical Ethics Committee of Rasoul Akram Hospital, Tehran, Iran (Approval No 375/105/D/93).

\section{Audiological examinations}

Categories of auditory performance (CAP) ${ }^{47}$ and speech intelligibility rating $(\mathrm{SIR})^{48}$ were used to assess hearing ability and speech intelligibility, respectively. The infants were screened at 2 months of age and were then referred to an audiologist after 2 years of age for audiometric tests, including CAP and SIR tests, where profound HLs $(>90 \mathrm{~dB})$ were identified in the patients. In the CAP test, the rating of auditory ability consists of the following eight categories: ${ }^{47}$ Score $0-$ no awareness of environmental sounds; Score 1 - awareness 
of environmental sounds; Score 2 - response to speech sounds; Score 3 - recognition of environmental sounds; Score 4-discrimination of at least two speech sounds; Score 5 - understanding of common phrases without lip reading; Score 6 - understanding of conversation without lip reading with a familiar talker; and Score 7 - use of a telephone with a familiar talker. The SIR test consists of five categories. ${ }^{48}$ Scores 1-5 depend on the spoken ability rating scale criteria, which are as follows: 5 - connected speech is intelligible to all listeners and the child is understood easily in everyday contexts; 4 - connected speech is intelligible to a listener who has a little experience of a deaf person's speech; 3 connected speech is intelligible to a listener who concentrates and lip-reads; 2 - connected speech is unintelligible, where intelligible speech is developing single words when context and lip-reading cues are available; and 1 - connected speech is unintelligible, where prerecognizable words in spoken language, the primary mode of communication, may be manual. All children received early intervention services within an average of 2 months after identification. This study was conducted in the Cochlear Implant Centre of the Hazrat Rasoul Akram Medical Complex, Tehran, Iran. The CAP and SIR assessments were conducted by two speech therapists during the follow-up period before implantation and at 6 months, 1 year, and 2 years after implantation. All 84 subjects had scores for both CAP and SIR before and after implantation. The children had to orally repeat the words/ sentences they heard from the test conductor who produced the stimuli with his/her mouth covered (all the subjects were tested by the same conductor) and were scored based on the number of (key)words they correctly repeated. The answers were then recorded.

\section{DNA extraction and polymerase chain reaction}

Total DNA was extracted from the peripheral blood sample of each individual using a QIAmap DNA Micro Kit (QIAGEN no 56304). The DNA was amplified for the mitochondrial $12 S$ $r R N A, t R N A^{L e u(U U R)}$, and ND1 genes (located near the MT-TL1 gene) and also for the nuclear GJB2 and GJB6 genes, using specific primers (Table 1).

Briefly, polymerase chain reaction (PCR) was performed in $25 \mu \mathrm{L}$ of reaction volumes containing 50-100 $\mathrm{ng}$ of genomic DNA, $2.5 \mu \mathrm{L}$ of $10 \times$ PCR buffer, $10 \mathrm{mM}$ of each dNTP, $1 \mathrm{mM}$ of $\mathrm{MgCl}_{2}, 10 \mathrm{pmol}$ of each primer, and $5 \mathrm{U}$ of Taq polymerase (CinnaGen, Tehran, Iran) to a final volume of $25 \mu \mathrm{L}$, topped up using distilled water. The reactions were performed in a thermal cycler (Eppendorf, Humburg, Germany), and the PCR products were examined on $1.5 \%$ agarose gel electrophoresis. The PCR conditions for amplification of the mitochondrial $12 S r R N A$ were as follows: initial DNA denaturation at $95^{\circ} \mathrm{C}$ for 5 minutes, then 35 cycles of denaturation at $95^{\circ} \mathrm{C}$ for 1 minute, annealing at $50^{\circ} \mathrm{C}$ for 1 minute, and extension at $72^{\circ} \mathrm{C}$ for 1 minute, followed by final extension at $72^{\circ} \mathrm{C}$ for 10 minutes. The PCR conditions for amplification of the mitochondrial $t R N A^{\operatorname{Leu(UUR)}}$ were as follows: initial DNA denaturation at $94^{\circ} \mathrm{C}$ for 5 minutes, then 35 cycles of denaturation at $94^{\circ} \mathrm{C}$ for 50 seconds, annealing at $55^{\circ} \mathrm{C}$ for 50 seconds, and extension at $72^{\circ} \mathrm{C}$ for 45 seconds, followed by final extension at $72^{\circ} \mathrm{C}$ for 10 minutes.

The primer sequences for the GJB6 gene used in this study were in accordance with previous studies. ${ }^{49-51}$ However, neither mutations nor deletions have been identified in the GJB6 gene in our patients. The PCR conditions for amplification of the nuclear GJB6 gene were as follows: initial DNA denaturation at $95^{\circ} \mathrm{C}$ for 5 minutes, then 35 cycles of denaturation at $95^{\circ} \mathrm{C}$ for 1 minute, annealing at $58.5^{\circ} \mathrm{C}$ for 1 minute, and extension at $72^{\circ} \mathrm{C}$ for 1 minute, followed by final extension at $72^{\circ} \mathrm{C}$ for 10 minutes. The PCR conditions for amplification of the nuclear GJB2 gene were performed in two steps, after initial DNA denaturation at $93^{\circ} \mathrm{C}$ for 3 minutes. The first step was done with five cycles of denaturation at $95^{\circ} \mathrm{C}$ for 1 minute, annealing at $59^{\circ} \mathrm{C}$ for 1 minute, and then final extension at $72^{\circ} \mathrm{C}$ for 1 minute.

Table I PCR primers of selected nuclear and mitochondrial genes

\begin{tabular}{|c|c|c|c|c|c|}
\hline Name & Gene & Primer name & Primer sequences & TM $\left({ }^{\circ} \mathrm{C}\right)$ & Amplicon size (bp) \\
\hline \multirow[t]{2}{*}{ I $2 S$ rRNA } & MT-RNRI & NG 78-F & F: 5'-CAGCACACACACACCGCTGC-3' & 57.2 & 950 \\
\hline & & NG 8I-R & R: 5'-GCTAAGGTTGTCTGGTAGTA-3' & & \\
\hline \multirow[t]{2}{*}{$t R N A^{\operatorname{Leu}(U U R)}$} & $M T-T L I^{\mathrm{a}}$ & ONP 82-F & F: 5'-CTCAACTTAGTATTATACCC-3' & 57.2 & 300 \\
\hline & & ONP I64-R & R: 5'-GATGGTGAGAGCTAAGGTCG-3' & & \\
\hline \multirow[t]{2}{*}{ Connexin 26} & GJB2 & Cxn 26-F & F: 5'-CTCССTGTTCTGTCCTAGCT-3' & 59 & 800 \\
\hline & & Cxn 26-R & R: 5'-CTCATCССТСТСАTGCTGTC-3' & & \\
\hline \multirow[t]{2}{*}{ Connexin 30} & GJB6 & Cxn 30-F & F: 5'-CACTTTCCCAAGGCCTCTTC-3' & 58.5 & 850 \\
\hline & & Cxn 30-R & R: 5'-GGTTGGTATTGCCTTCTGGA-3' & & \\
\hline
\end{tabular}

Note: ${ }^{\mathrm{N} D}$ I gene is covered by MT-TLI primers.

Abbreviations: $P C R$, polymerase chain reaction; $F$, forward; $R$, reverse; TM, temperature. 
The second step was carried out with 26 cycles of denaturation at $94^{\circ} \mathrm{C}$ for 45 seconds, annealing at $59^{\circ} \mathrm{C}$ for $45 \mathrm{sec}-$ onds, and extension at $72^{\circ} \mathrm{C}$ for 45 seconds, followed by final extension at $72^{\circ} \mathrm{C}$ for 8 minutes.

\section{DNA sequencing and analysis of variants}

The PCR products were sequenced with the respective forward or reversed primers on an ABI 3700 sequencer (Takapo Zist Company, Tehran, Iran) and compared with the revised Cambridge Reference Sequence and the NCBI Reference Sequence Database (http://www.ncbi.nlm.nih.gov/refseq/) using the FinchTV program version 1.4.0. Identification of the nucleotide changes was verified through MITOMAP (http://mitomap.org/MITOMAP) and the Human Gene Mutation Database, 2007.

\section{RNA secondary structure analysis}

The RNA fold software from the Institute for Theoretical Chemistry, University of Vienna (rna@tbi.univie.ac.at;
http://rna.tbi.univie.ac.at/cgi-bin/RNAfold.cgi), was used to predict the RNA secondary structure based on minimum energy requirements and base pairing (Figures 1 and 2).

\section{Statistical analysis}

The independent $t$-test using Statistical Package for the Social Sciences, version 13, was used to analyze the relationship between CAP and SIR with cochlear implantation in the $\mathrm{GJB}^{-}$and GJB2 ${ }^{+}$groups; $P$-values $<0.05$ were regarded as statistically significant (Table 2).

\section{Results}

In this study, the MT-RNR1 (12sRNA) and MT-TL1 $\left(t R N A^{\operatorname{Leu}(U U R)}\right)$ genes were analyzed. Polymorphisms that were detected in MT-RNR1 included G709A in eight patients (9.6\%), T1243C in two patients $(2.4 \%)$, T980C in three patients $(3.6 \%), \mathrm{T} 1406 \mathrm{C}$ in one patient $(1.2 \%), \mathrm{G} 930 \mathrm{~A}$ in one patient $(1.2 \%)$, and $\mathrm{T} 1189 \mathrm{C}$ in three patients $(3.6 \%)$. No mutation was found in the MT-TL1 ( $t R N A^{\operatorname{Leu(UUR)})}$ gene.

\begin{tabular}{|c|c|c|c|}
\hline Group & Gene & Wild type (A) & Polymorphism (B) \\
\hline GJB2- patient & $\begin{array}{l}\text { T980C } \\
\text { (MT-RNR1) }\end{array}$ & 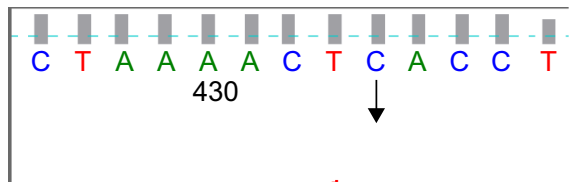 & 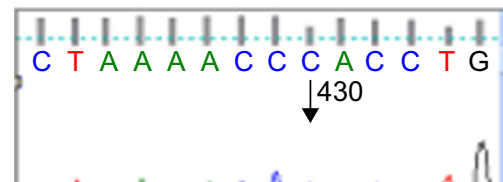 \\
\hline $\begin{array}{l}\text { GJB2- patient/ } \\
\text { GJB2+ patient }\end{array}$ & $\begin{array}{l}\text { G709A } \\
(M T-R N R 1)\end{array}$ & 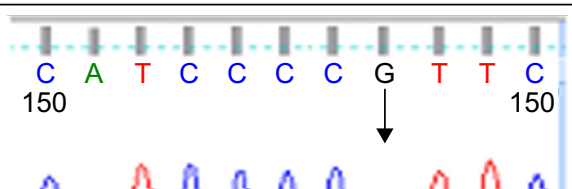 & A G C A T C C C C A T TC C \\
\hline GJB2+ patient & $\begin{array}{l}\text { T1189C } \\
(M T-R N R 1)\end{array}$ & $\int_{0}$ & 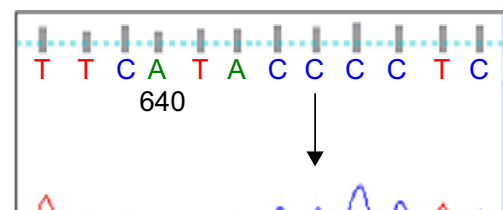 \\
\hline GJB2- patient & $\begin{array}{l}\text { T1243C } \\
(M T-R N R 1)\end{array}$ & 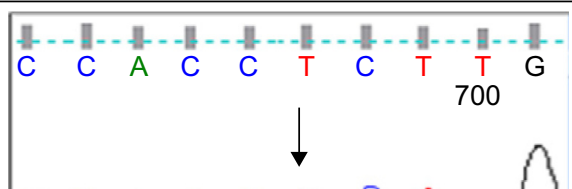 & 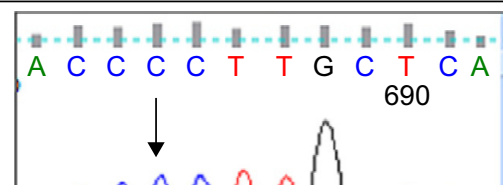 \\
\hline
\end{tabular}

Figure I (Continued) 


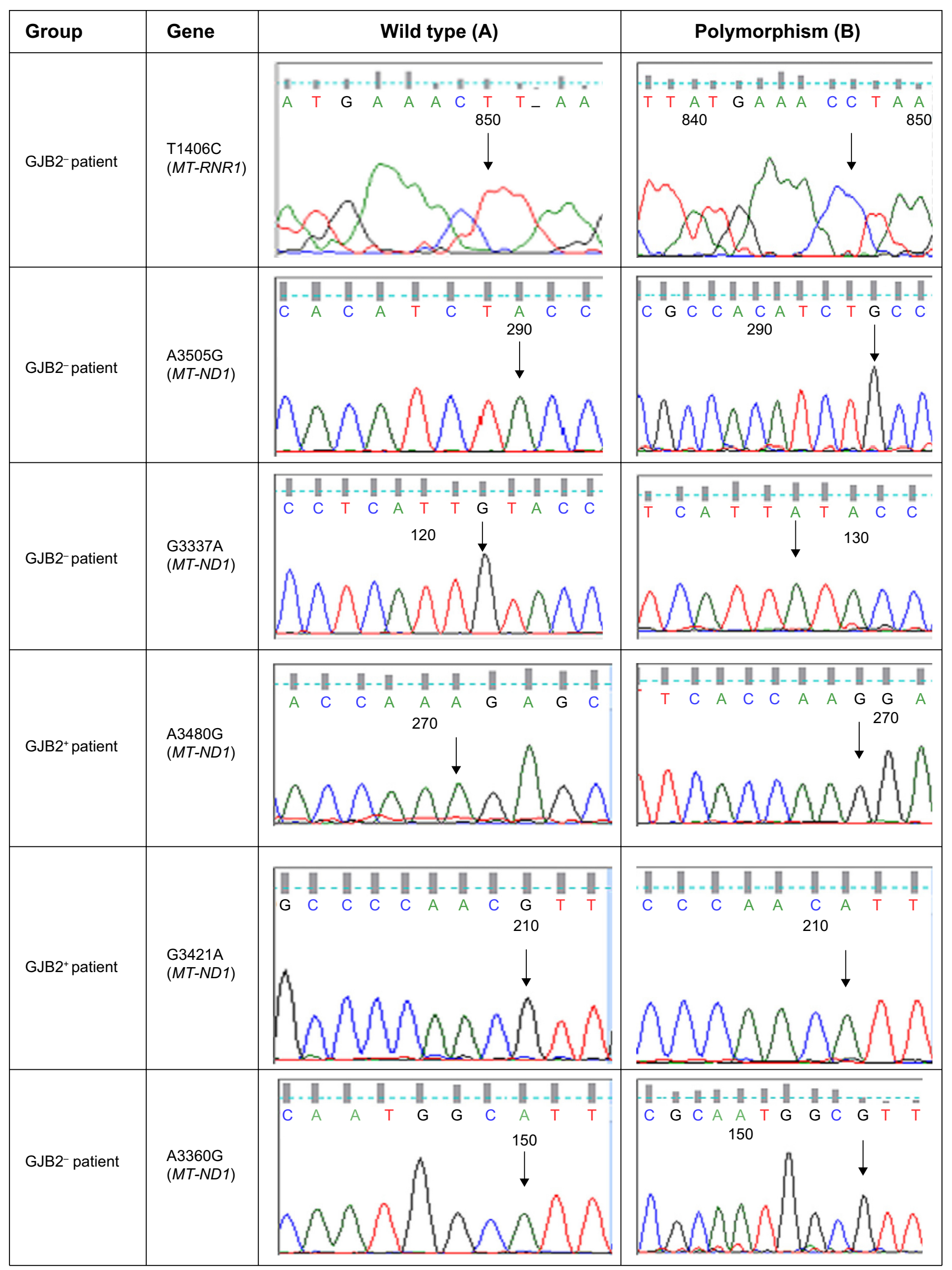

Figure I (Continued) 


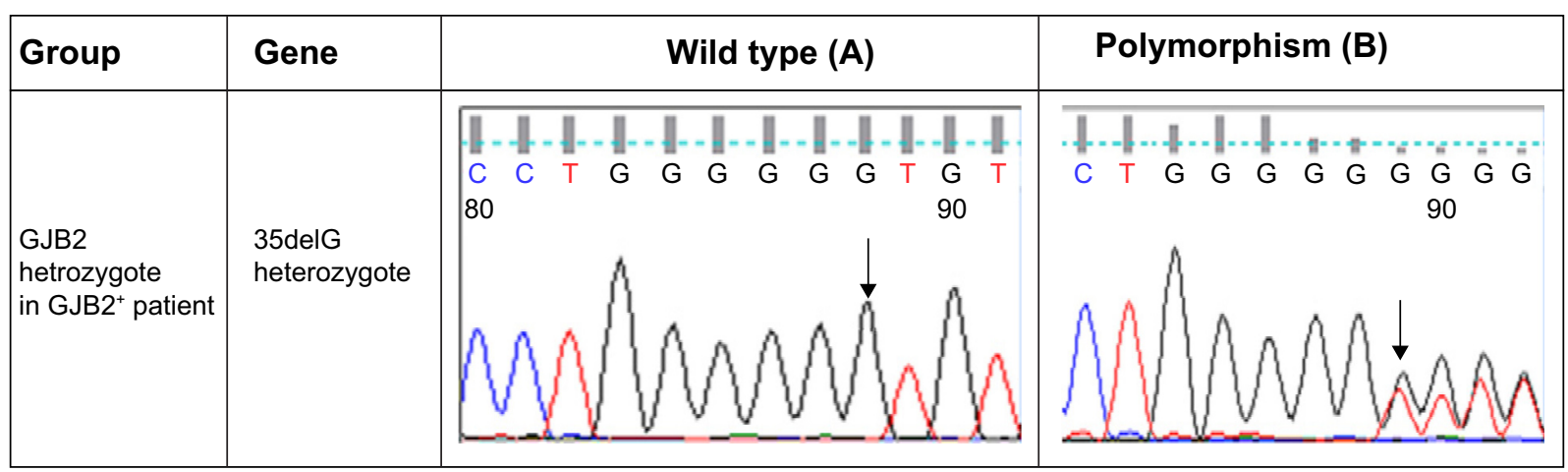

Figure I Comparison of sequence analysis of the polymorphism in MT-RNRI and MT-NDI and heterozygous GJB2 genes among patients with GJB2 mutation (GJB2+) and without $\mathrm{GJB2}$ mutation (GJB2-).

Note: The arrows indicate the location of the nucleotide changes in wild type vs polymorphism.

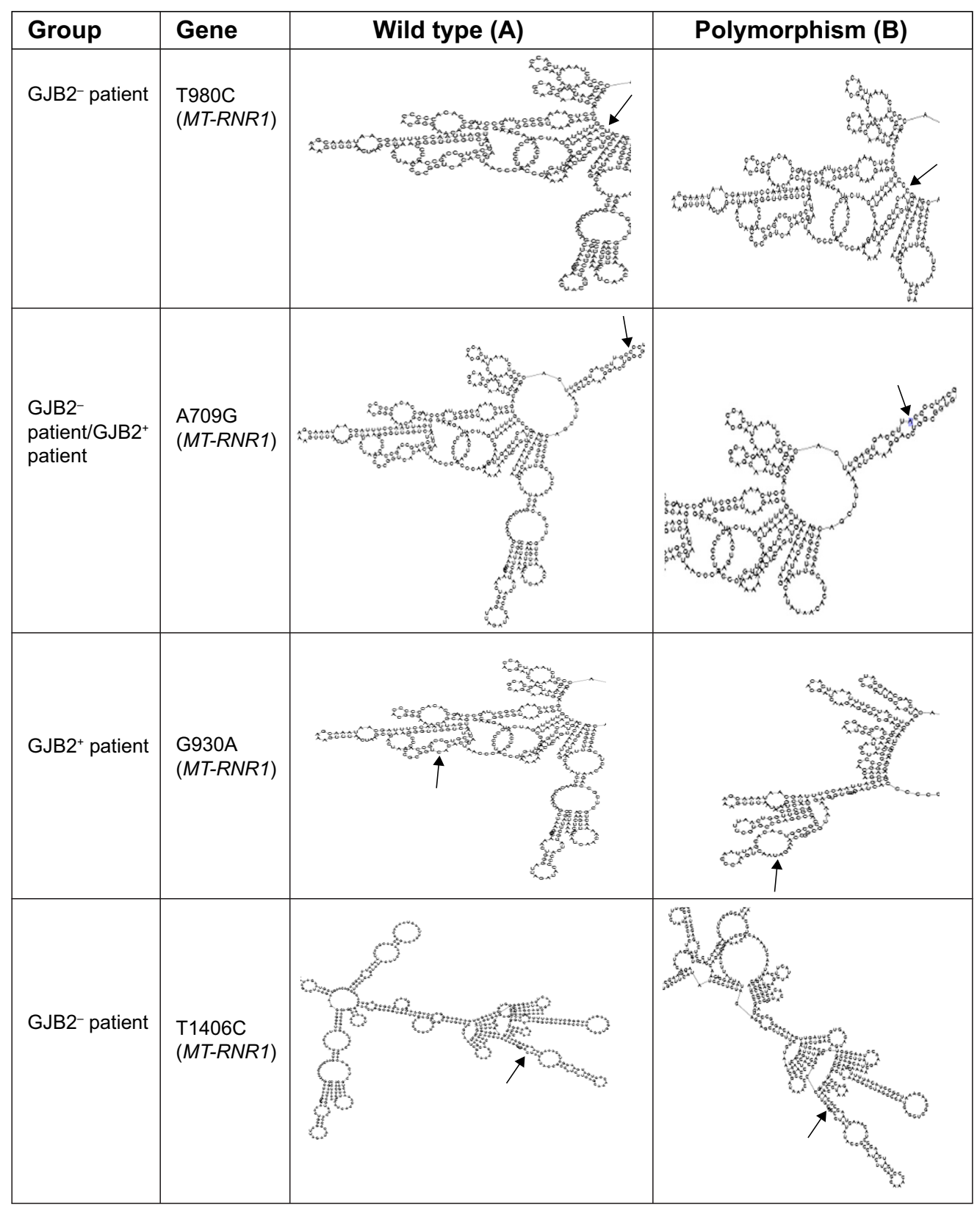




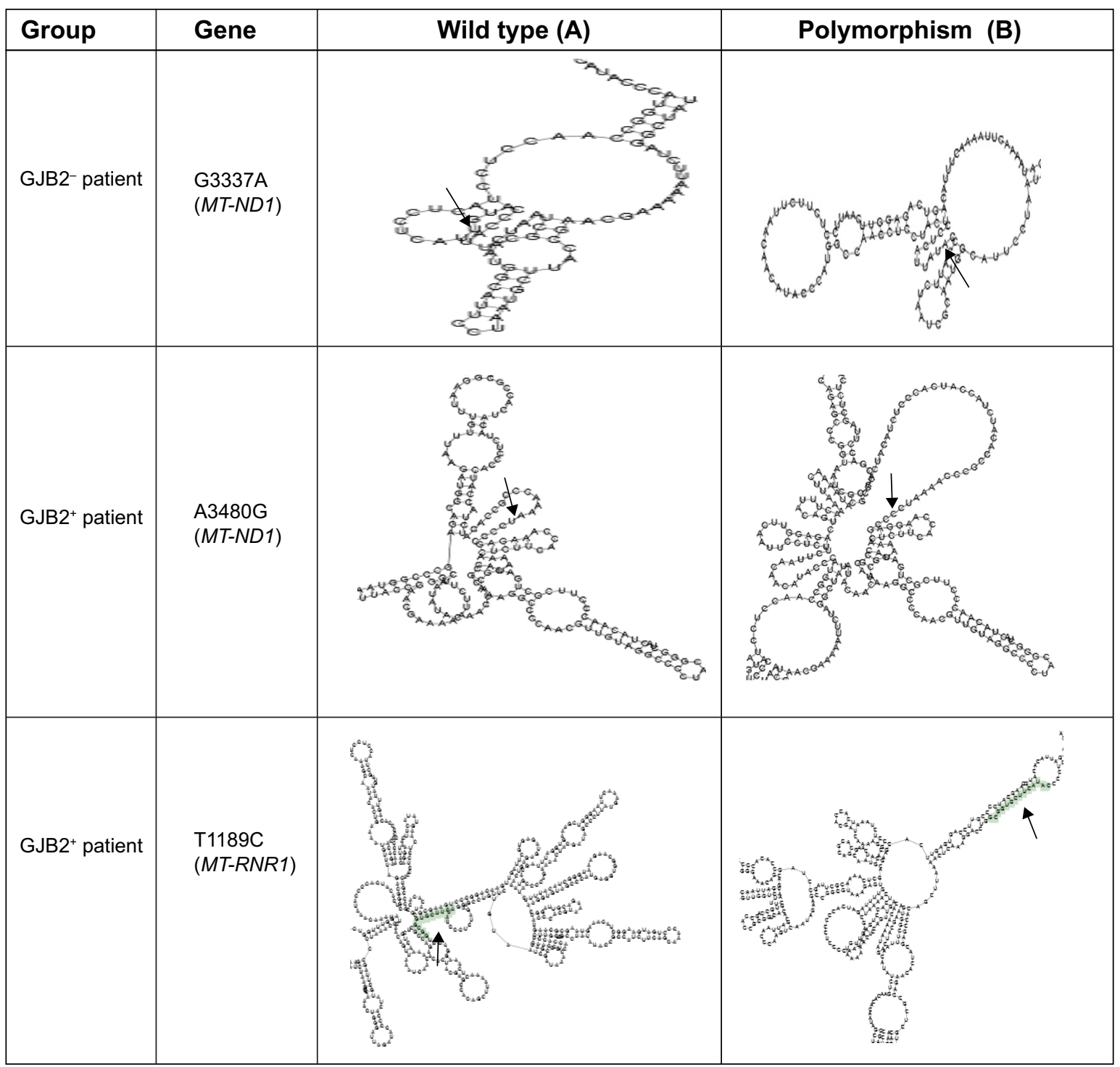

Figure 2 Comparison of RNA secondary structure analysis of wild type and polymorphic predicted in MT-RNRI and MT-NDI genes among patients with GJB2 mutation $\left(\mathrm{GJB} 2^{+}\right)$and without GJB2 mutation (GJB2-).

Note: The arrows indicate the location of the nucleotide changes based on RNA secondary structure analysis in wild type vs polymorphism.

Additionally, eight polymorphisms in the MT-ND1 (NADH dehydrogenase I) gene were found, including A3360G (1.2\%), A3505G (2.4\%), A3339G (1.2\%), G3337A (2.4\%), G3392C (1.2\%), G3483A (1.2\%), A3480G (3.6\%), and G3421A (2.4\%). Here, all mtDNA mutations were homoplasmic, while only one - A3339G (1.2\%) - was heteroplasmic mtDNA
ND1 polymorphism. Two GJB2+ patients with V153I and R184P did not show any mitochondrial RNR1 and ND1 mutations. In addition, all GJB2 ${ }^{-}$and $\mathrm{GJB} 2^{+}$patients revealed the presence of the $\mathrm{A} 750 \mathrm{G}$ and $\mathrm{A} 1438 \mathrm{G}$ polymorphisms in the $M T-R N R 1$ gene. Sequence analysis in the nuclear GJB2 and GJB6 genes demonstrated that no mutation in nuclear GJB6

Table 2 Statistical analysis of SIR and CAP in the GJB2- and GJB2+ patients using independent $t$-test

\begin{tabular}{|c|c|c|c|c|c|}
\hline \multirow{2}{*}{$\begin{array}{l}\text { Audiological } \\
\text { examinations }\end{array}$} & \multicolumn{2}{|c|}{ Before cochlear implantation (mean \pm SD) } & \multicolumn{2}{|c|}{ After cochlear implantation (mean \pm SD) } & \multirow[t]{2}{*}{$P$-value } \\
\hline & GJB2 $^{+}$patient $(\mathrm{N}=60)$ & GJB2- patient $(\mathrm{N}=\mathbf{2 4})$ & GJB2 $^{+}$patient $(N=60)$ & GJB2 $^{-}$patient $(\mathrm{N}=24)$ & \\
\hline SIR & $1 \pm 0$ & $\mathrm{I} \pm 0$ & $2.93 \pm 0.54$ & $2.92 \pm 0.88$ & 0.663 \\
\hline CAP & $1 \pm 0$ & $\mathrm{I} \pm 0$ & $6.75 \pm 1.36$ & $5.58 \pm 0.79$ & $0.002 *$ \\
\hline
\end{tabular}

Notes: There is a significant difference $(P<0.05)$ between the CAP score of GJB2- patients compared to GJB2 ${ }^{+}$patients, while there is no significant difference in the SIR score between GJB2- and GJB2 ${ }^{+}$patients. The score of CAP in GJB2 ${ }^{+}$patients is higher than that of GJB2- patients, which shows that this group comprises better candidates for cochlear implant than the other group. CAP and SIR assessments were done 2 years after cochlear implant. *Statistically significant $(P<0.05)$.

Abbreviations: SIR, speech intelligibility rating; CAP, category of auditory performance; SD, standard deviation. 


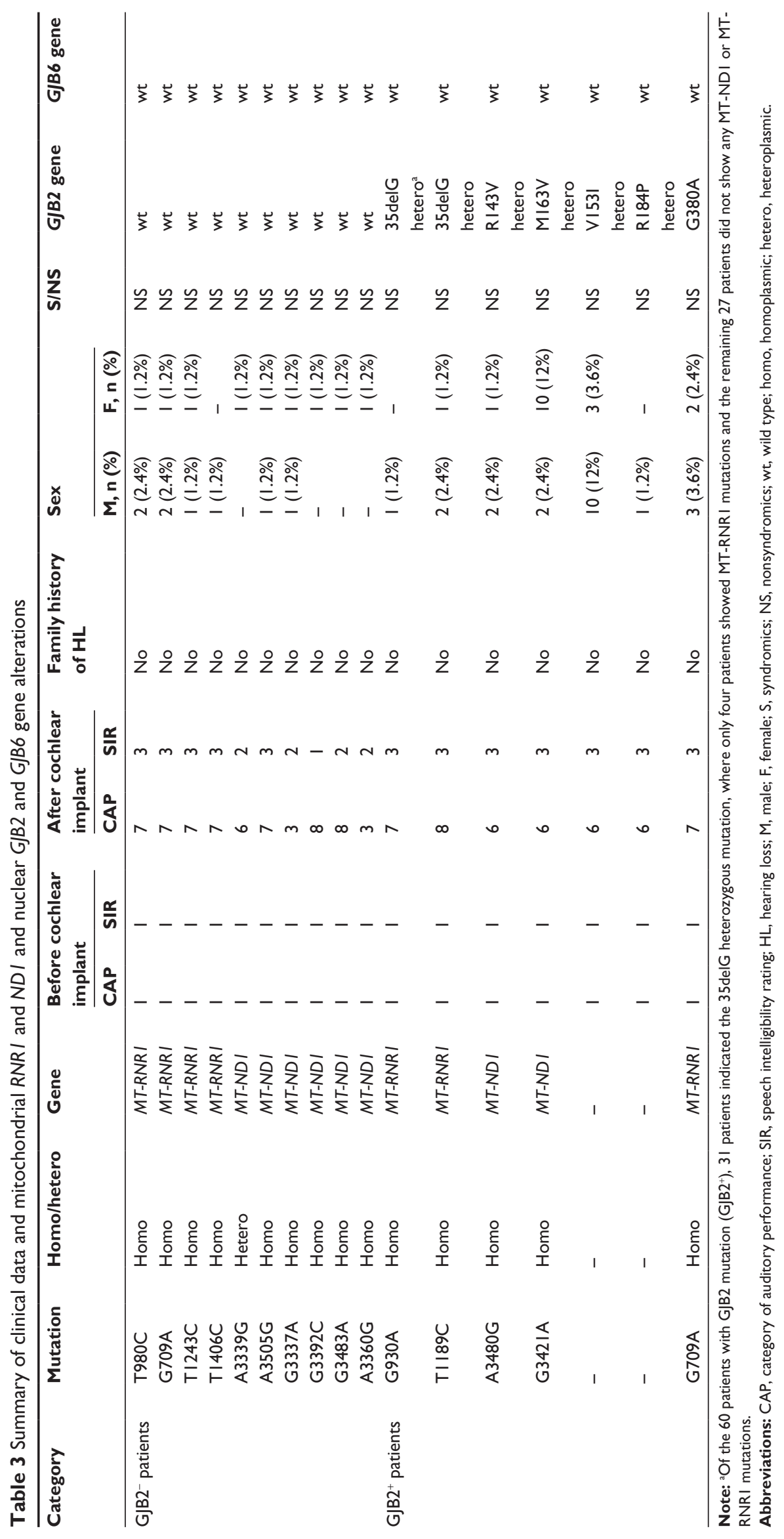



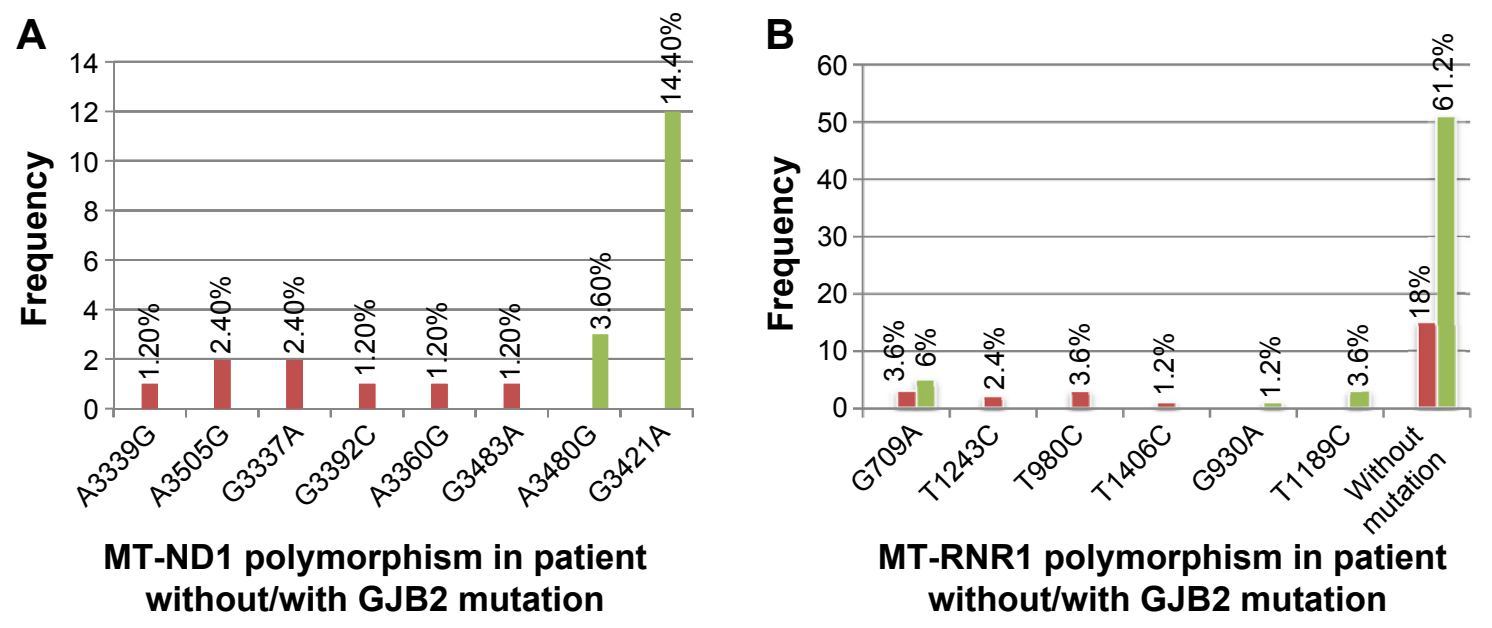

- Patient without GJB2 mutation $\square$ Patient with GJB2 mutation

Figure 3 Frequency of polymorphism MT-RNRI and MT-NDI genes in patients without GJB2 mutation (GJB2-) and patients with GJB2 mutation (GJB2+). Notes: (A) MT-NDI gene and (B) MT-RNRI gene.

gene was detected in all GJB2- and GJB2 ${ }^{+}$groups. Of the 84 individuals, no GJB2 mutation was observed in 24 patients $\left(\mathrm{GJB}^{-}\right)$, but different types of GJB2 mutations were observed among the $60 \mathrm{GJB}^{+}$patients (Table 3; Figure 3).

\section{Discussion}

In this study, the impact of the mitochondrial 12SrRNA (MT$R N R 1), t R N A^{\operatorname{Leu}(U U R)}(M T-T L 1)$, and ND1 variations among 84 random Iranian patients were compared between patients with GJB2 mutation (GJB2+) and without GJB2 mutation $\left(\mathrm{GJB}^{-}\right)$undergoing cochlear implants, which had not been examined by earlier Iranian researchers. These hotspots are recognized to be among the most frequent causes of hearing impairment. ${ }^{52}$ Mitochondria play an important function in metabolism, thus mutations in mitochondrial genes result in many metabolic diseases. ${ }^{53}$ In the present study, we analyzed three fragments of mtDNA, namely $12 S \mathrm{r} R N A$ (MT-RNR1), tRNA $A^{\operatorname{Leu}(U U R)}$ (MT-TL1), and ND1, and two fragments of nDNA, namely GJB2 (Cx26) and GJB6, in 84 subjects with nonsyndromic HL. All patients (GJB2- and GJB2 ${ }^{+}$) were found to have the $\mathrm{A} 750 \mathrm{G}$ and $\mathrm{A} 1438 \mathrm{G}$ polymorphisms in the $M T-R N R 1$ gene, which is in agreement with previous studies that reported that the A750G, A1438G, A4769G, A8860G, and A15326G polymorphisms are common to mtDNA sequences from Africans, Asians, and Europeans. ${ }^{54}$ Therefore, the polymorphisms in the $M T-R N R 1$ gene are not the cause of deafness and hearing impairment in Iranian patients. However, among the eight polymorphisms in the MT-NDI (NADH dehydrogenase I) gene, A3505G and A3480G are associated with prostate cancer, while G3337A and G3421A are associated with cardiomyopathy ${ }^{55}$ and pancreatic cancer, ${ }^{56}$ respectively.

It should be noted that late-onset and gradual worsening of hearing impairment may reflect the tendency of the mitochondrion to accumulate mutations with aging, due to its genomic instability. As previously reported, ${ }^{57}$ mitochondrial mutation plays an important role in cochlear implantation, whereas in our study, mitochondrial polymorphisms also indicate candidacy for cochlear implantation. Additionally, RNA secondary structure analysis demonstrated that the RNA at G930A, T1189C, and A3480G had different structures to compare the wild type, where it is possible that these polymorphisms and their correlation with the GJB2 mutation have more effect on deafness.

The association between mitochondrial and nuclear mutations with aminoglycoside exposure is quite variable, where aminoglycosides are probably only one of the factors interacting with the mutation in determining the deafness phenotype and play a role only in $\sim 20 \%$ of patients. ${ }^{1,58-61}$ Several studies have reported that patients carrying the $\mathrm{A} 1555 \mathrm{G}$ mutation exposed to aminoglycosides develop more severe deafness with an earlier onset. ${ }^{31,59,60,62-64}$ However, consistent with the other studies, ${ }^{58-61,65,66}$ our study showed that even in the absence of aminoglycoside exposure, mitochondrial polymorphisms could be responsible for hearing impairment. Previous studies revealed the mitochondrial $\mathrm{m} 1555 \mathrm{~A}>\mathrm{G},{ }^{67} \mathrm{~m} .1005 \mathrm{~T}>\mathrm{C},{ }^{68}$ and $\mathrm{m} .921 \mathrm{~T}>\mathrm{C}^{68}$ mutations among Iranian patients, while these mentioned mutations were not detected in our patients with HL. Additionally, a study indicated the high carrier frequency of the nuclear GJB2 mutation (35delG) in the north of Iran. ${ }^{69}$ 


\section{Conclusion}

In conclusion, our finding indicates that a combination of polymorphisms in mitochondrial and nuclear genes may increase the penetrance of deafness and that there may be an association between nuclear gene variation and mitochondrial deafness with cochlear implant in Iranian patients. Therefore, the pathogenicity impact of mtDNA and nDNA variants and their correlation with other conditions should be established. Therefore, further genetic and functional studies are required in order to help individuals decide whether to undergo cochlear implantation.

\section{Acknowledgments}

We would like to thank all the participants from the Rasoul Akram Hospital, Tehran, Iran, for blood donation.

\section{Author contributions}

Conceived and designed the experiments: MH. Performed the experiments: MB. Analyzed the data and contributed the reagents/materials/analysis tools: $\mathrm{MDA}, \mathrm{MRH}, \mathrm{HA}$, and MF. Wrote the manuscript, contributed to the discussion, and reviewed the article: BK and FA. All authors contributed toward data analysis, drafting and critically revising the paper and agree to be accountable for all aspects of the work.

\section{Disclosure}

The authors report no conflicts of interest in this work.

\section{References}

1. Guaran V, Astolfi L, Castiglione A, et al. Association between idiopathic hearing loss and mitochondrial DNA mutations: a study on 169 hearingimpaired subjects. Int J Mol Med. 2013;32(4):785-794.

2. Chen JN, Ho KY, Juan KH. Sensorineural hearing loss in MELAS syndrome - case report. Kaohsiung J Med Sci. 1998;14(8):519-523.

3. Yuan H, Jiang S, Yang W, Guo W, Cao J, Dai P. [Screening for mitochondrial $1555(\mathrm{G})$ mutation in patients with aminoglycoside antibioticinduced deafness]. Zhonghua Yi Xue Yi Chuan Xue Za Zhi. 1999;16(3): $141-144$.

4. Simdon J, Watters D, Bartlett S, Connick E. Ototoxicity associated with use of nucleoside analog reverse transcriptase inhibitors: a report of 3 possible cases and review of the literature. Clin Infect Dis. 2001;32(11):1623-1627.

5. Bravo O, Ballana E, Estivill X. Cochlear alterations in deaf and unaffected subjects carrying the deafness-associated $\mathrm{A} 1555 \mathrm{G}$ mutation in the mitochondrial 12S rRNA gene. Biochem Biophys Res Commun. 2006; 344(2):511-516.

6. Young WY, Zhao L, Qian Y, et al. Variants in mitochondrial tRNAGlu, tRNAArg, and tRNAThr may influence the phenotypic manifestation of deafness-associated 12S rRNA A1555G mutation in three Han Chinese families with hearing loss. Am J Med Genet A. 2006;140(20): 2188-2197.

7. Zhao H, Li R, Wang Q, et al. Maternally inherited aminoglycosideinduced and nonsyndromic deafness is associated with the novel C1494T mutation in the mitochondrial 12S rRNA gene in a large Chinese family. Am J Hum Genet. 2004;74(1):139-152.
8. Xing G, Chen Z, Cao X. Mitochondrial rRNA and tRNA and hearing function. Cell Res. 2007;17(3):227-239.

9. Berrettini S, Forli F, Passetti S, et al. Mitochondrial non-syndromic sensorineural hearing loss: a clinical, audiological and pathological study from Italy, and revision of the literature. Biosci Rep. 2008;28(1): 49-59.

10. Miyagawa M, Nishio SY, Ikeda T, Fukushima K, Usami SI. Massively parallel DNA sequencing successfully identifies new causative mutations in deafness genes in patients with cochlear implantation and EAS. PLoS One. 2013;8(10):e75793.

11. Li JZ, Hu YQ, Wang SH, et al. [Mutations of $\mathrm{Cx} 26$ gene in patients with NSHL and intracellular distribution of two mutants]. Yi Chuan. 2009;31(7):705-712.

12. Li Z, Li R, Chen J, et al. Mutational analysis of the mitochondrial $12 \mathrm{~S}$ rRNA gene in Chinese pediatric subjects with aminoglycoside-induced and non-syndromic hearing loss. Hum Genet. 2005;117(1):9-15.

13. Ballana E, Morales E, Rabionet R, et al. Mitochondrial 12S rRNA gene mutations affect RNA secondary structure and lead to variable penetrance in hearing impairment. Biochem Biophys Res Commun. 2006;341(4):950-957.

14. Gurtler N, Schmuziger N, Kim Y, Mhatre AN, Jungi M, Lalwani AK. Audiologic testing and molecular analysis of $12 \mathrm{~S}$ rRNA in patients receiving aminoglycosides. Laryngoscope. 2005;115(4): 640-644.

15. Scaglia F, Hsu CH, Kwon H, et al. Molecular bases of hearing loss in multi-systemic mitochondrial cytopathy. Genet Med. 2006;8(10): 641-652.

16. Shenkar R, Navidi W, Tavaré S, et al. The mutation rate of the human mtDNA deletion mtDNA4977. Am J Hum Genet. 1996;59(4):772.

17. Hatefi Y. The mitochondrial electron transport and oxidative phosphorylation system. Annu Rev Biochem. 1985;54(1):1015-1069.

18. Rezvani Z, Didari E, Arastehkani A, et al. Fifteen novel mutations in the mitochondrial NADH dehydrogenase subunit 1, 2, 3, 4, 4L, 5 and 6 genes from Iranian patients with Leber's hereditary optic neuropathy (LHON). Mol Biol Rep. 2013;40(12):6837-6841.

19. Salehi MH, Kamalidehghan B, Houshmand M, et al. Gene expression profiling of mitochondrial oxidative phosphorylation (OXPHOS) complex I in Friedreich ataxia (FRDA) patients. PLoS One. 2014;9(4): e94069.

20. Mousavizadeh K, Askari M, Arian H, et al. Association of human mtDNA mutations with autism in Iranian patients. J Res Med Sci. 2013; 18(10):926.

21. Nia SS, Azadfar P, Akbari L, et al. New pathogenic variations of mitochondrial DNA in Alzheimer disease! J Res Med Sci. 2013;18(3): 269-269.

22. Kalahroudi VG, Kamalidehghan B, Kani AA, et al. Two novel tyrosinase (TYR) gene mutations with pathogenic impact on oculocutaneous albinism type 1 (OCA1). PLoS One. 2014;9(9):e106656.

23. Colagar AH, Mosaieby E, Seyedhassani SM, et al. T4216C mutation in NADH dehydrogenase I gene is associated with recurrent pregnancy loss. Mitochondrial DNA. 2013;24(5):610-612.

24. Ghaffarpour M, Mahdian R, Fereidooni F, Kamalidehghan B, Moazami N, Houshmand M. The mitochondrial ATPase6 gene is more susceptible to mutation than the ATPase 8 gene in breast cancer patients. Cancer Cell Int. 2014;14:21.

25. Anderson S, Bankier AT, Barrell BG, et al. Sequence and organization of the human mitochondrial genome. Nature. 1981;290(5806): 457-465.

26. Shakhssalim N, Houshmand M, Kamalidehghan B, et al. The mitochondrial C16069T polymorphism, not mitochondrial D310 (D-loop) mononucleotide sequence variations, is associated with bladder cancer. Cancer Cell Int. 2013;13(1):120.

27. Akouchekian M, Houshmand M, Akbari MHH, Kamalidehghan B, Dehghan M. Analysis of mitochondrial ND1 gene in human colorectal cancer. J Res Med Sci. 2011;16(1):50.

28. Sutton GJ, Rowe SJ. Risk factors for childhood sensorineural hearing loss in the Oxford region. Br J Audiol. 1997;31(1):39-54. 
29. Pediatrics AAO, Association AS-L-H. Year 2000 position statement: principles and guidelines for early hearing detection and intervention programs. Pediatrics. 2000;106(4):798-817.

30. Nance WE, Lim BG, Dodson KM. Importance of congenital cytomegalovirus infections as a cause for pre-lingual hearing loss. J Clin Virol. 2006;35(2):221-225

31. Casano RA, Johnson DF, Bykhovskaya Y, Torricelli F, Bigozzi M, Fischel-Ghodsian N. Inherited susceptibility to aminoglycoside ototoxicity: genetic heterogeneity and clinical implications. Am J Otolaryngol 1999;20(3):151-156.

32. Tang H-Y, Hutcheson E, Neill S, Drummond-Borg M, Speer M, Alford RL. Genetic susceptibility to aminoglycoside ototoxicity: how many are at risk? Genet Med. 2002;4(5):336-345.

33. Bindoff L, Howell N, Poulton J, et al. Abnormal RNA processing associated with a novel tRNA mutation in mitochondrial DNA. A potential disease mechanism. J Biol Chem. 1993;268(26):19559-19564.

34. van den Bosch B, de Coo I, Hendrickx A, et al. Increased risk for cardiorespiratory failure associated with the A3302G mutation in the mitochondrial DNA encoded tRNALeu (UUR) gene. Neuromuscul Disord. 2004;14(10):683-688.

35. Helm M, Brulé H, Friede D, Giegé R, Pütz D, Florentz C. Search for characteristic structural features of mammalian mitochondrial tRNAs. RNA. 2000;6(10):1356-1379.

36. Li X, Fischel-Ghodsian N, Schwartz F, Yan Q, Friedman RA, Guan MX. Biochemical characterization of the mitochondrial tRNASer (UCN) T7511C mutation associated with nonsyndromic deafness. Nucleic Acids Res. 2004;32(3):867-877.

37. Wilch E, Zhu M, Burkhart KB, et al. Expression of GJB2 and GJB6 is reduced in a novel DFNB1 allele. Am J Hum Genet. 2006;79(1): $174-179$.

38. Grifa A, Wagner CA, D'Ambrosio L, et al. Mutations in GJB6 cause nonsyndromic autosomal dominant deafness at DFNA3 locus. Nat Genet. 1999;23(1):16-18.

39. Zhao H-B, Kikuchi T, Ngezahayo A, White T. Gap junctions and cochlear homeostasis. J Membr Biol. 2006;209(2-3):177-186.

40. Taniguchi M, Matsuo H, Shimizu S, et al. Carrier frequency of the GJB2 mutations that cause hereditary hearing loss in the Japanese population. J Hum Genet. 2015;60(10):613-617.

41. Abe S, Usami S, Shinkawa H, Kelley PM, Kimberling WJ. Prevalent connexin 26 gene (GJB2) mutations in Japanese. J Med Genet. 2000 37(1):41-43.

42. Ohtsuka A, Yuge I, Kimura S, et al. GJB2 deafness gene shows a specific spectrum of mutations in Japan, including a frequent founder mutation. Hum Genet. 2003;112(4):329-333.

43. Smith RJ, Bale JF, White KR. Sensorineural hearing loss in children. Lancet. 2005;365(9462):879-890.

44. Kumar NM, Gilula NB. The gap junction communication channel. Cell. 1996;84(3):381-388.

45. Kelsell D, Dunlop J, Stevens H, et al. Connexin 26 mutations in hereditary non-syndromic sensorineural deafness. Nature. 1997;387(6628): 80-83.

46. Green GE, Scott DA, McDonald JM, Woodworth GG, Sheffield VC, Smith RJ. Carrier rates in the midwestern United States for GJB2 mutations causing inherited deafness. JAMA. 1999;281(23):2211-2216.

47. Archbold S, Lutman ME, Marshall DH. Categories of auditory performance. Ann Otol Rhinol Laryngol Suppl. 1995;166:312-314.

48. Allen C, Nikolopoulos TP, Dyar D, O’Donoghue GM. Reliability of a rating scale for measuring speech intelligibility after pediatric cochlear implantation. Otol Neurotol. 2001;22(5):631-633.

49. Kahrizi K, Shafeghati Y, Daneshi A, Jogataie M-T. Delta (GJB6D13S1830) is not a common cause of nonsyndromic hearing loss in the Iranian population. Arch Iran Med. 2005;8(2):104-108.

50. Mahdieh N, Raeisi M, Shirkavand A, Bagherian H, Akbari MT, Zeinali S. Investigation of GJB6 large deletions in Iranian patients using quantitative real-time PCR. Clin Lab. 2009;56(9-10):467-471.
51. Sadeghi A, Sanati MH, Alasti F, Hashemzadeh Chaleshtori M, Ataei M. Mutation analysis of connexin 26 gene and del (GJB6-D13S1830) in patients with hereditary deafness from two provinces in Iran. Iran J Biotechnol. 2005;3:255-258.

52. Dzhemileva LU, Posukh OL, Tazetdinov AM, et al. [Analysis of mitochondrial $12 \mathrm{~S}$ rRNA and tRNA(Ser(UCN)) genes in patients with nonsyndromic sensorineural hearing loss from various regions of Russia]. Genetika. 2009;45(7):982-991.

53. Shadel GS. Expression and maintenance of mitochondrial DNA: new insights into human disease pathology. Am J Pathol. 2008;172(6): 1445-1456.

54. Herrnstadt C, Elson JL, Fahy E, et al. Reduced-median-network analysis of complete mitochondrial DNA coding-region sequences for the major African, Asian, and European haplogroups. Am J Hum Genet. 2002;70(5):1152-1171.

55. Brandon M, Baldi P, Wallace DC. Mitochondrial mutations in cancer. Oncogene. 2006;25(34):4647-4662.

56. Jansen RJ, Fonseca-Williams S, Bamlet WR, et al. Detection of DNA damage in peripheral blood mononuclear cells from pancreatic cancer patients. Mol Carcinog. 2015;54(10):1220-1226.

57. Sudo A, Takeichi N, Hosoki K, Saitoh S. Successful cochlear implantation in a patient with mitochondrial hearing loss and $\mathrm{m} .625 \mathrm{G}>\mathrm{A}$ transition. J Laryngol Otol. 2011;125(12):1282-1285.

58. Fischel-Ghodsian N. Mitochondrial deafness. Ear Hear. 2003;24(4): 303-313.

59. Casano RA, Bykhovskaya Y, Johnson DF, et al. Hearing loss due to the mitochondrial A1555G mutation in Italian families. Am J Med Genet. 1998;79(5):388-391.

60. Estivill X, Govea N, Barcelo A, et al. Familial progressive sensorineural deafness is mainly due to the mtDNA A $1555 \mathrm{G}$ mutation and is enhanced by treatment with aminoglycosides. Am J Human Genet. 1998; 62(1):27-35

61. Prezant TR, Agapian JV, Bohlman MC, et al. Mitochondrial ribosomal RNA mutation associated with both antibiotic-induced and nonsyndromic deafness. Nat Genet. 1993;4(3):289-294.

62. Braverman I, Jaber L, Levi H, et al. Audiovestibular findings in patients with deafness caused by a mitochondrial susceptibility mutation and precipitated by an inherited nuclear mutation or aminoglycosides. Arch Otolaryngol Head Neck Surg. 1996;122(9):1001-1004.

63. El-Schahawi M, de Munain AL, Sarrazin A, et al. Two large Spanish pedigrees with nonsyndromic sensorineural deafness and the mtDNA mutation at nt 1555 in the 12S rRNA gene evidence of heteroplasmy. Neurology. 1997;48(2):453-456.

64. Noguchi Y, Yashima T, Ito T, Sumi T, Tsuzuku T, Kitamura K. Audiovestibular findings in patients with mitochondrial A1555G mutation. Laryngoscope. 2004;114(2):344-348.

65. Hutchin T, Higashi K, Fischel-Ghodsian N, Stoneking M, Arnos C. A molecular basis for human hypersensitivity of aminoglyscoside antibiotics. Nucleic Acids Res. 1993;21(18):4174-4179.

66. Matsunaga T, Kumanomido H, Shiroma M, Ohtsuka A, Asamura K, Usami Si. Deafness due to A1555G mitochondrial mutation without use of aminoglycoside. Laryngoscope. 2004;114(6):1085-1091.

67. Zohour MM, Akbari M, Chaleshtori MH. Frequency of the mitochondrial A1555G mutation in Iranian patients with non-syndromic hearing impairment. Indian J Sci Technol. 2012;5(10):3378-3383.

68. Dowlati MA, Derakhshandeh-peykar P, Houshmand M, et al. Novel nucleotide changes in mutational analysis of mitochondrial 12SrRNA gene in patients with nonsyndromic and aminoglycoside-induced hearing loss. Mol Biol Rep. 2013;40(3):2689-2695.

69. Chaleshtori MH, Farrokhi E, Shahrani M, et al. High carrier frequency of the GJB2 mutation (35delG) in the north of Iran. Int J Pediatr Otorhinolaryngol. 2007;71(6):863-867. 


\section{Publish your work in this journal}

Therapeutics and Clinical Risk Management is an international, peerreviewed journal of clinical therapeutics and risk management, focusing on concise rapid reporting of clinical studies in all therapeutic areas, outcomes, safety, and programs for the effective, safe, and sustained use of medicines. This journal is indexed on PubMed Central, CAS,

EMBase, Scopus and the Elsevier Bibliographic databases. The manuscript management system is completely online and includes a very quick and fair peer-review system, which is all easy to use. Visit http://www.dovepress.com/testimonials.php to read real quotes from published authors.

Submit your manuscript here: http://www.dovepress.com/therapeutics-and-clinical-risk-management-journal 